\title{
Low temperature impact on photosynthetic parameters of coffee genotypes
}

\author{
Fábio Luiz Partelli(1), Henrique Duarte Vieira ${ }^{(2)}$, Alexandre Pio Viana( ${ }^{(2)}$, Paula Batista-Santos ${ }^{(3)}$, \\ Ana Paula Rodrigues ${ }^{(4)}$, António Eduardo Leitão ${ }^{(3)}$ and José Cochicho Ramalho(3)
}

\begin{abstract}
(1)Universidade Federal de Goiás, Escola de Agronomia e Engenharia de Alimentos, Campus II Samambaia, Caixa Postal 131, CEP 74001-970 Goiânia, GO, Brazil. E-mail: partelli@yahoo.com.br ${ }^{(2)}$ Universidade Estadual do Norte Fluminense Darcy Ribeiro, Centro de Ciências e Tecnologias Agropecuárias, Avenida Alberto Lamego, № 2.000, Parque Califórnia, CEP 28013-602 Campos dos Goytacazes, RJ, Brazil. E-mail: henrique@uenf.br, pirapora@uenf.br ${ }^{(3)}$ Instituto de Investigação Científica Tropical, Centro de Ecofisiologia, Bioquímica e Biotecnologia Vegetal, Avenida República, Quinta do Marquês, 2784-505 Oeiras, Portugal. E-mail: peichler@iict.pt, cochichor@iict.pt ${ }^{(4) I n s t i t u t o ~ S u p e r i o r ~ d e ~ A g r o n o m i a, ~ T a p a d a ~ d a ~ A j u d a, ~ 1349-017 ~ L i s b o a, ~ P o r t u g a l . ~ E-m a i l: ~ a n a d r @ i s a . u n l . p t ~}$
\end{abstract}

\begin{abstract}
The objective of this work was to evaluate photoprotective mechanisms related to low positive temperatures in Coffea canephora (Conilon clones 02 and 153) and C. arabica ('Catucaí' IPR 102) genotypes, involved in cold temperature tolerance. To accomplish this, one-year-old plants were successively submitted to: temperature decrease of $0.5^{\circ} \mathrm{C}$ day ${ }^{-1}$, from $25 / 20^{\circ} \mathrm{C}$ to $13 / 8^{\circ} \mathrm{C}$; a three-day chilling cycle at $13 / 4^{\circ} \mathrm{C}$; and a recovery period of 14 days $\left(25 / 20^{\circ} \mathrm{C}\right)$. During the experiment, leaf gas exchange, chlorophyll $a$ fluorescence and leaf photosynthetic pigment content were evaluated. Total activity of ribulose-1,5-bisphosphate carboxylase/ oxygenase (Rubisco) and ribulose-5-phosphate kinase (Ru5PK) were quantified to measure the activity of photosynthesis key enzymes. All genotypes showed low temperature sensitivity, but displayed diverse cold impact and recovery capabilities regarding the photosynthetic-related parameters studied. Catucaí IPR 102 cultivar showed better ability to cope with cold stress than the Conilon clones, especially Conilon 02, and had full recovery of leaf gas exchange, fluorescence parameters, enzymatic activity, and higher contents of the photoprotective pigments zeaxanthin and lutein.
\end{abstract}

Index terms: Coffea, carotenoids, photoprotection, photosynthesis, rubisco.

\section{Impacto de baixas temperaturas em parâmetros fotossintéticos de genótipos de cafeeiro}

Resumo - O objetivo deste trabalho foi avaliar mecanismos de fotoproteção relacionados a temperaturas baixas positivas em genótipos de Coffea canephora (clones Conilon 02 e 153) e C. arabica ('Catucaí' IPR 102), envolvidos na tolerância a baixas temperaturas. Para tal, plantas com um ano de idade foram expostas sucessivamente a: decréscimo da temperatura $\left(0,5^{\circ} \mathrm{C}\right.$ dia $\left.^{-1}\right)$, de $25 / 20^{\circ} \mathrm{C}$ até $13 / 8^{\circ} \mathrm{C}$; um ciclo de três dias a $13 / 4^{\circ} \mathrm{C}$; e a 14 dias de recuperação $\left(25 / 20^{\circ} \mathrm{C}\right)$. Durante o experimento, foram avaliadas as trocas gasosas, a fluorescência da clorofila $a$ e os teores de pigmentos fotossintéticos foliares. Foram quantificadas a atividade total da ribulose-1,5-bisfosfato carboxilase/oxigenase (Rubisco) e da ribulose-5-fosfato quinase (Ru5PK), para medir a atividade de enzimas-chave da fotossíntese. Todos os genótipos mostraram sensibilidade a baixas temperaturas, mas tolerância e capacidade de recuperação diferentes no que respeita aos diversos parâmetros fotossintéticos estudados. A cultivar Catucaí IPR 102 apresenta maior capacidade de suportar o estresse do frio que os clones de Conilon, em particular o Conilon 02, com completa recuperação dos parâmetros de trocas gasosas foliares, de fluorescência e das atividades enzimáticas, e teores mais elevados dos pigmentos fotoprotetores zeaxantina e luteína.

Termos para indexação: Coffea, carotenoides, fotoproteção, fotossíntese, rubisco.

\section{Introduction}

The genus Coffea has approximately 100 species, with commercial relevance for $C$. arabica and C. canephora (Davis et al., 2006). Brazil is the world's largest coffee producer and exporter. Coffee is a major source of income, employment and development in the producing and processing regions.
Low temperatures interfere with the photosynthetic process in several ways. They lower stomatal conductance, photochemical efficiency of the photosystem (PS) II, thylakoid electron transport rate, enzyme activity and carbon metabolism, as well as the photosynthetic pigment complex systems (Suzuki et al., 2008) and membrane lipids (Campos et al., 2003). 
Coffee is particularly sensitive to cold, especially $C$. arabica, C. canephora and C. dewevrei (DaMatta et al., 1997; Ramalho et al., 2003), which are responsible for over $99 \%$ of the world's coffee production. Previous works showed that photosynthesis is strongly reduced below $18^{\circ} \mathrm{C}$ (Ramalho et al., 2003), while temperatures around $4^{\circ} \mathrm{C}$ dramatically depress photosynthetic performance and yield (DaMatta et al., 1997; Silva et al., 2004). However, a gradual exposure to low positive temperatures highlighted the possibility of photosynthetic cold acclimation in some coffee genotypes (Ramalho et al., 2003), which was related to membrane stability (Campos et al., 2003). Oxidative stress often occurs when plants remain under adverse environmental conditions (drought, high irradiance, extreme temperatures, and nutritional stresses) due to changes in the light energy capture balance and in its use (Demmig-Adams et al., 1995; Ramalho et al., 2003). In fact, when the energy trapped by the photosynthetic pigments exceeds consumption requirements for carbon assimilation, increased production of highly reactive molecules of chlorophyll $\left({ }^{3} \mathrm{Chl}\right)$ and oxygen $\left({ }^{1} \mathrm{O}_{2}, \mathrm{O}_{2}{ }^{-}\right.$, $\mathrm{H}_{2} \mathrm{O}_{2}$ and $\mathrm{OH}$ ) may occur, leading to damages in the photosystems, in enzymes, in membrane lipids and in DNA (Suzuki et al., 2008). Therefore, the xanthophyll cycle is an important photoprotective mechanism when excess of light energy occurs, since it performs thermal energy dissipation, preventing overproduction of highly reactive molecules of chlorophyll and oxygen (Ma et al., 2003; Ramalho et al., 2003; Cai et al., 2007).

Understanding the physiological and biochemical response mechanisms to low temperatures in Coffea can contribute to selecting tolerant genotypes and improving crop management. Therefore, the objective of this work was to contribute to the characterization of response mechanisms that might permit $C$. canephora and $C$. arabica plants to cope with low temperatures.

\section{Material and Methods}

The experiment was done at the Centro de Ecofisiologia, Bioquímica e Biotecnologia Vegetal, Instituto de Investigação Científica Tropical, in Oeiras, Portugal. One-year-old plants of Coffea canephora cv. Conilon, clones 02 (early ripening) and 153 (late ripening), widely cultivated genotypes, and $C$. arabica cv. Catucaí IPR 102, a newly bred genotype with potential cold tolerance, were used. Plants were grown in 3-L pots containing soil:sand (4:1) substrate and organic matter plus chemical nutrients, in a greenhouse with controlled environment to prevent night temperatures lower than $14^{\circ} \mathrm{C}$ during the winter. They were then transferred to walk-in growth chambers (10000 EHHF, Aralab, Portugal) with $750-900 \mu \mathrm{mol} \mathrm{m} \mathrm{m}^{-2} \mathrm{~s}^{-1}$ of irradiance, external air $\mathrm{CO}_{2}$ concentration of $380 \mu \mathrm{L} \mathrm{L}^{-1}, 70 \%$ relative humidity, 12-h photoperiod and $25 / 20^{\circ} \mathrm{C}$ (day/night) temperatures for 15 days to allow plant stabilization in these conditions set as control. Afterwards, the plants were exposed to a gradual reduction in temperature of $0.5^{\circ} \mathrm{C}$ day $^{-1}$, from $25 / 20^{\circ} \mathrm{C}$ to $13 / 8^{\circ} \mathrm{C}$, for 24 days, to allow the expression of potential responses to low temperatures. After that, plants were exposed to a three-day chilling at $4^{\circ} \mathrm{C}$ at night and in the first four hours of the next day, and to $13^{\circ} \mathrm{C}$ during daytime (three days at $13 / 4^{\circ} \mathrm{C}$ ), followed by a recovery period of 14 days in which the temperature was raised to $20 / 15^{\circ} \mathrm{C}$ in the first day and to $25 / 20^{\circ} \mathrm{C}$ for the following 13 days. All determinations were performed in similar recently mature leaves of the upper part of the plants.

Photosynthetic net $\mathrm{CO}_{2}$ assimilation (A) and stomatal water vapor $\left(\mathrm{g}_{s}\right)$ conductance rates, as well as internal $\mathrm{CO}_{2}$ concentrations $\left(\mathrm{C}_{\mathrm{i}}\right)$ were measured in ten leaves, using a portable IRGA open system (CIRAS 1, PP Systems, England). Measurements were carried out on five plants per genotype at 9, 11, 13, 15 and $17 \mathrm{~h}$. The photosynthesis and the fluorescence data collected during the light period represent the average of those five points, integrating the whole day period.

Chlorophyll (Chl) $a$ fluorescence and gas exchange were evaluated on the same leaves at the same times and also in the dark at the end of the night period using a PAM-2000 system (H. Walz, Effeltrich, Germany). $\operatorname{Minimum}\left(\mathrm{F}_{\mathrm{o}}\right)$ and maximal $\left(\mathrm{F}_{\mathrm{m}}\right)$ fluorescence, as well as the photochemical efficiency of photosystem II $\left(\mathrm{F}_{\mathrm{v}} / \mathrm{F}_{\mathrm{m}}\right)$ were determined in the dark. The photochemical $\left(\mathrm{q}_{\mathrm{P}}\right)$ and nonphotochemical $\left(\mathrm{q}_{\mathrm{NP}}\right)$ quenchings (Kooten \& Snell, 1990), the estimation of the quantum yield of photosynthetic noncyclic electron transport $\left(\phi_{\mathrm{e}}\right)$ (Genty et al., 1989) and the photosystem II (PSII) energy conversion efficiency $\left(\mathrm{F}_{\mathrm{v}} / \mathrm{F}_{\mathrm{m}}\right.$ ) (Krüpa et al., 1993) were obtained under steady-state photosynthetic conditions (irradiance of $550 \mu \mathrm{mol} \mathrm{m} \mathrm{m}^{-2} \mathrm{~s}^{-1}$ and saturating flashes of $6,000 \mu \mathrm{mol} \mathrm{m} \mathrm{m}^{-2} \mathrm{~s}^{-1}$ ) and calculated as described by Ramalho et al. (2002). Both measurements were taken from five plants per genotype (two measurements per 
leaf) at night and during the day, and were done on the same leaves.

Photosynthetic pigments were analyzed in eight samples (with four foliar discs of $0.5 \mathrm{~cm}^{2}$ each) randomly collected from recently mature leaves from four different plants, at the end of the dark period and after two hours of illumination. Samples were immediately frozen in liquid nitrogen at $-80^{\circ} \mathrm{C}$ until analysis. The homogenization of leaf tissues and subsequent reversed-phase HPLC separation, identification and quantification of individual carotenoids was based on Ramalho et al. (1997). The de-epoxidation state $[\mathrm{DEPS}=(0.5 \mathrm{~A}+\mathrm{Z}) /(\mathrm{V}+\mathrm{A}+\mathrm{Z})]$, involving the xanthophyll cycle and the antheraxanthin (A), violaxanthin (V) and zeaxanthin (Z) components, was calculated as in Schindler et al. (1994). Chlorophyll content was evaluated spectrophotometrically, according to Lichtenthaler (1987).

Four samples (with four foliar discs of $0.5 \mathrm{~cm}^{2}$ each) weretakenfromthesameleavesusedforpigmentanalyses after two hours of illumination to measure the activity of photosynthesis key enzymes. Homogenization and evaluation of ribulose-1,5-bisphosphate carboxylase/ oxygenase (Rubisco) and ribulose-5-phosphate kinase (Ru5PK) total activity were done as described by Maroco et al. (1999).

Data were subjected to analyses of variance, at $5 \%$ of probability, in a factorial arrangement with two factors (genotype and temperature, including the recovery period) for pigment and for enzyme activity, and three factors (genotype and temperature, including the recovery and daytime periods) for gas exchange and fluorescence. Treatment means were compared by Tukey's test at $5 \%$ of probability.

\section{Results and Discussion}

The several daily determinations of leaf gas exchange and fluorescence parameters did not show significant differences. Accordingly, diurnal points were presented as a global daytime average for these parameters.

Stomatal closure is frequently pointed out as one of the first limitations for photosynthesis under low temperatures (Ramalho et al., 2003). However, despite the significant and positive correlation $(\mathrm{r}=0.80)$ between $\mathrm{A}$ and $\mathrm{g}_{\mathrm{s}}$ (Figure $1 \mathrm{~A}$ and $\mathrm{B}$ ), the decrease in A was not caused by a lower $C_{i}$ supply, since this parameter gradually increases when A decreases (Figure $1 \mathrm{C}$ ), as reflected in a significant and negative correlation $(\mathrm{r}=-0.86)$ between $\mathrm{C}_{\mathrm{i}}$ and A. Conilon 02 presented higher $\mathrm{C}_{\mathrm{i}}$ values during the entire experiment. The A values were strongly affected by the cold in the three genotypes. From $13 / 8^{\circ} \mathrm{C}$ until the first day of the recovery period, A was dramatically affected, and showed negligible values in the three genotypes. However, after that, significant differences were detected amongst the genotypes, and showed recoveries of 100 (Catucaí IPR 102), 75 (Conilon 153) and 50\% (Conilon 02) of their respective control values by the end of the experiment (Figure $1 \mathrm{~A})$.

Concomitantly, $\mathrm{g}_{\mathrm{s}}$ was enhanced in all genotypes, but with different recovery, with Catucaí IPR 102 with higher values than the control $\left(25 / 20^{\circ} \mathrm{C}\right)$ seven days after the end of the stress period, which is significantly higher than for the two other Conilon genotypes. $C_{i}$ decreased during the recovery period, stabilizing around 200-250 $\mu \mathrm{L} \mathrm{L}^{-1}$, which could be enough to obtain maximum A values, particularly in Catucaí IPR 102, which completely recovered for $\mathrm{A}, \mathrm{g}_{\mathrm{s}}$ and $\mathrm{C}_{\mathrm{i}}$. Thus, low A values during exposure to low temperatures was not caused by $\mathrm{CO}_{2}$ restriction at the carboxylation sites due to stomatal closure. Instead, they would be related to metabolic limitations caused by low temperature. Reductions in $\mathrm{A}$ and in growth rate under seasonal low temperatures (minimum of $8^{\circ} \mathrm{C}$ ) in field conditions (Silva et al., 2004), and A decreases in C. arabica cv. Red Catuaí and C. canephora cv. Conilon in the winter $\left(19.4 / 13.9^{\circ} \mathrm{C}\right)$ (DaMatta et al., 1997) were also reported. Red Catuaí showed strong A depression, followed by a $g_{s}$ decrease of $75 \%$ and a $C_{i}$ increase of $34 \%$, while Conilon showed lower impact on A and insignificant changes in $\mathrm{g}_{\mathrm{s}}$ and $\mathrm{C}_{\mathrm{i}}$, corroborating the data obtained in this experiment and pointing out to A limitations other than stomatal.

The moderately low temperature of $18 / 13^{\circ} \mathrm{C}$ induced a significant decrease in Rubisco activity in Catucaí IPR 102 and Conilon 153 (Figure 2 A), which was not affected further at lower temperatures. These results agree with those reported for C. canephora $\mathrm{cv}$. Apoatã and for $C$. dewevrei under similar conditions (Ramalho et al., 2003). Interestingly, Conilon 02 was significantly affected only after chilling; when Catucaí IPR 102 also showed lower values, but Conilon 153 had values close to the control $\left(25 / 20^{\circ} \mathrm{C}\right)$. The reduction in the activity of Rubisco with cold confirms the suggestion that A was not limited by $C_{i}$, and could be related to several factors. In fact, under 
cold conditions, negative effects on Rubisco could result from the activity of highly reactive molecules that are commonly overproduced in cold sensitive genotypes, due to the lack of substrate, chemical energy and reducing power (Maroco et al., 1999), or to monosaccharide accumulation (Ramalho et al., 2003).
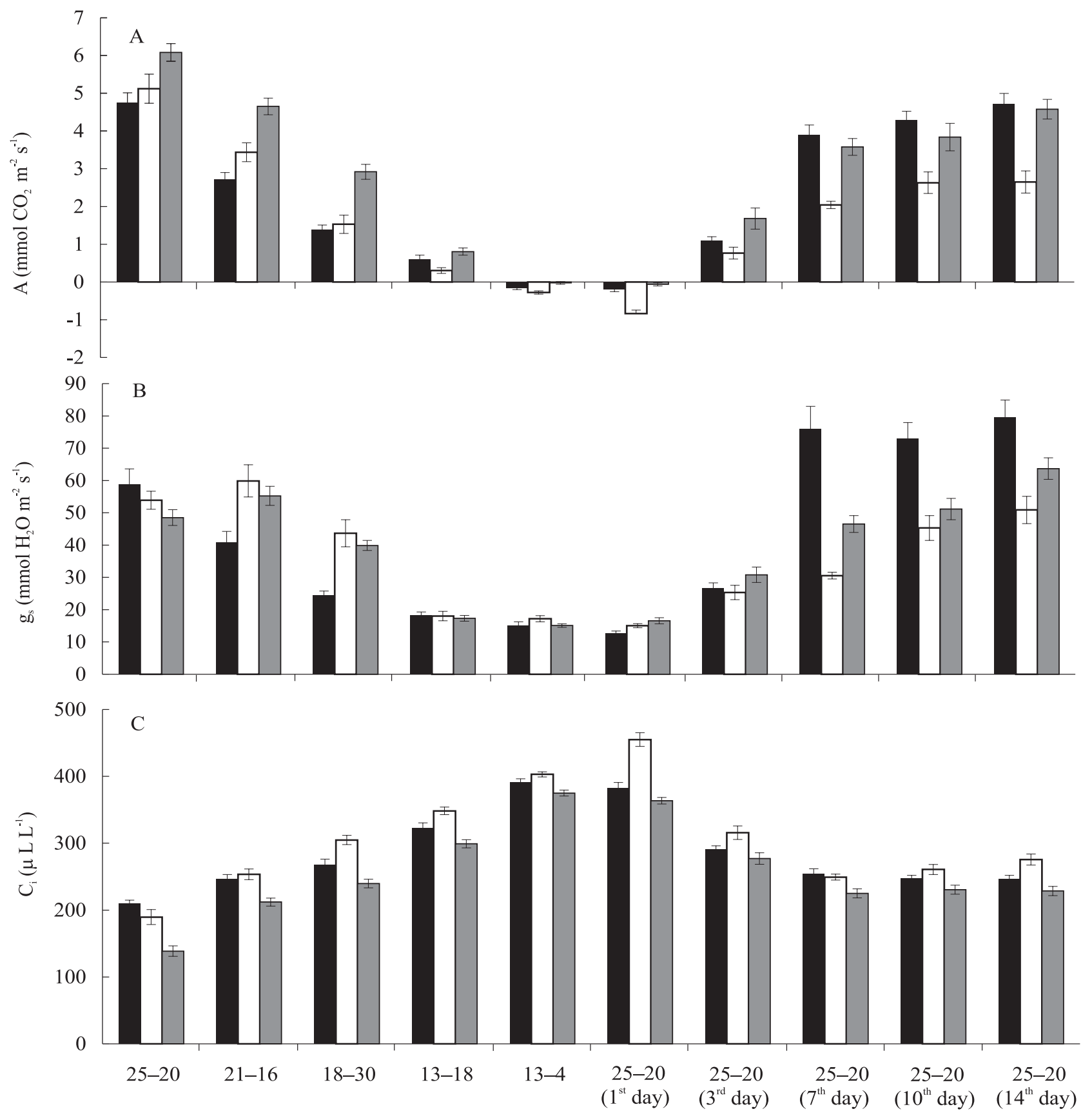

Diurnal-nocturnal temperature $\left({ }^{\circ} \mathrm{C}\right)$

Catucaí IPR $102 \square$ Conilon $02 \square$ Conilon 153

Figure 1. Changes in: $A$, net photosynthesis; $B$, stomatal conductance $(\mathrm{gs})$ rates; and $\mathrm{C}$, internal concentration of $\mathrm{CO}_{2}\left(\mathrm{C}_{\mathrm{i}}\right)$ in Coffea sp. Catucaí IPR 102, Conilon 02 and Conilon 153 genotypes submitted to a gradual decrease of temperature (25-20 ${ }^{\circ} \mathrm{C}$ to $13-8^{\circ} \mathrm{C}$ ) for 24 days, three days at $13-4^{\circ} \mathrm{C}$, and to a recovery period of 14 days at $25-20^{\circ} \mathrm{C}$. Bars represent standard error $(\mathrm{n}=25)$. Least significant difference $(\mathrm{p}<0.05)$ of 0.69 and 0.94 for genotypes and periods, respectively; coefficient of variation, $45.18 \%$. 
Furthermore, Ru5PK activity (Figure 2 B) decreased in Catucaí IPR 102 and Conilon 153, which may be caused by low availability of RuBP (Fredeen et al., 1990), thus strengthening the hypothesis that the observed strong A reduction with cold might include limited substrate availability for the Calvin cycle.

Conilon 02 showed lower effects on the Rubisco and Ru5PK activities than the other genotypes during gradual temperature reduction, and complete recovery was observed by the end of the experiment. This suggests that, at least in the recovery period, there are other restraints for the photosynthetic metabolism in Conilon 02, limiting A recovery to only $50 \%$ of its initial control value at $25 / 20^{\circ} \mathrm{C}$. Furthermore, Catucaí IPR 102 promptly and completely recovered enzyme activity after the end of stress, which agrees with complete A recovery; while Conilon 153 showed partial recovery of A (75\%), Rubisco $(73 \%)$ and Ru5PK ( $81 \%)$ activities by the end of the experiment.

Chlorophyll $a$ fluorescence can give reliable information on chloroplast light energy capture and processing. With the gradual temperature decline, the maximum quantum efficiency of PSII $\left(\mathrm{F}_{\mathrm{v}} / \mathrm{F}_{\mathrm{m}}\right)$ and the maximum fluorescence $\left(\mathrm{F}_{\mathrm{m}}\right)$ decreased (Figure $3 \mathrm{~A}$ and B), as also observed in Zea mays under $5^{\circ} \mathrm{C}$ (Ribas-Carbo et al., 2000). These values started to increase in the three genotypes during the third day of recovery, showing total recovery ten days after exposure to chilling. However, during the exposure to cold, the impact on $F_{v} / F_{m}$
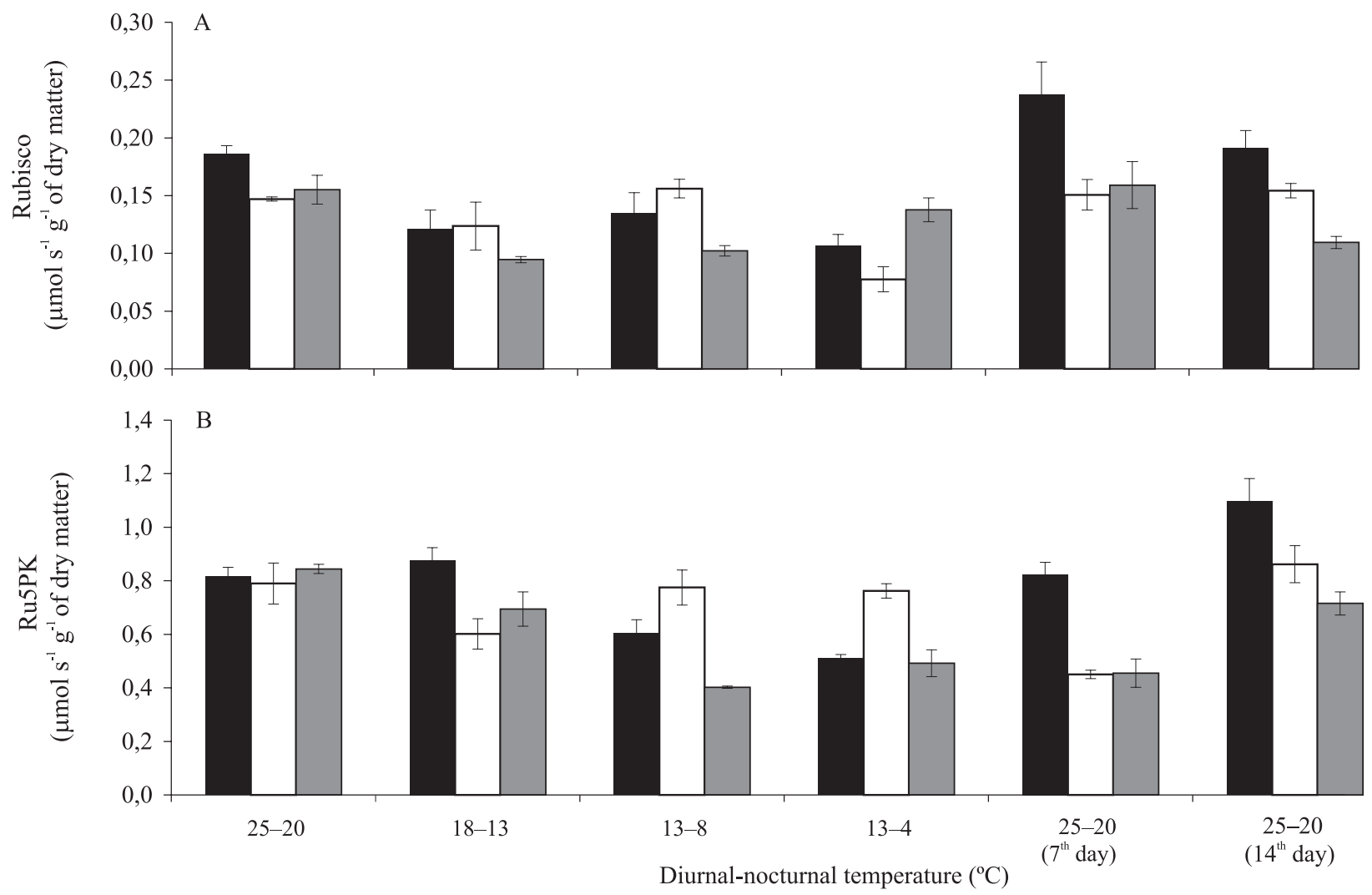

- Catucaí IPR $102 \square$ Conilon $02 \square$ Conilon 153

Figure 2. Changes in: A, Rubisco; and B, Ru5PK activities ( $\mu \mathrm{mol} \mathrm{s} \mathrm{g}^{-1}$ dry weight) in leaves collected after two hours of illumination in Coffea sp. Catucaí IPR 102, Conilon 02 and Conilon 153 genotypes submitted to: a gradual decrease of temperature $\left(25-20^{\circ} \mathrm{C}\right.$ to $\left.13-8^{\circ} \mathrm{C}\right)$ for 24 days; three days at $13-4^{\circ} \mathrm{C}$; and to a recovery period of 0.046 and 0.057 for genotypes and periods, respectively; CV, 19.25\%. Bars represent standard error $(\mathrm{n}=4)$. For Rubisco, least significant difference (LSD, 5\%) of 14 days at $25-20^{\circ} \mathrm{C}$. For Ru5PK, LSD of 0.173 and 0.212 for genotypes and periods, respectively; coefficient of variation (CV), $14.53 \%$. 
and $\mathrm{F}_{\mathrm{v}} / \mathrm{F}_{\mathrm{m}}$, (Figure $4 \mathrm{~A}$ ), cannot be attributed solely to photochemical damages, since the diurnal and nocturnal zeaxanthin content increased with the cold conditions (Table 1). In fact, some xanthophylls are well-known photoprotective substances that act by thermal dissipation, thus avoiding energy overpressure of the photosynthetic apparatus (Demmig-Adams et al., 1995).
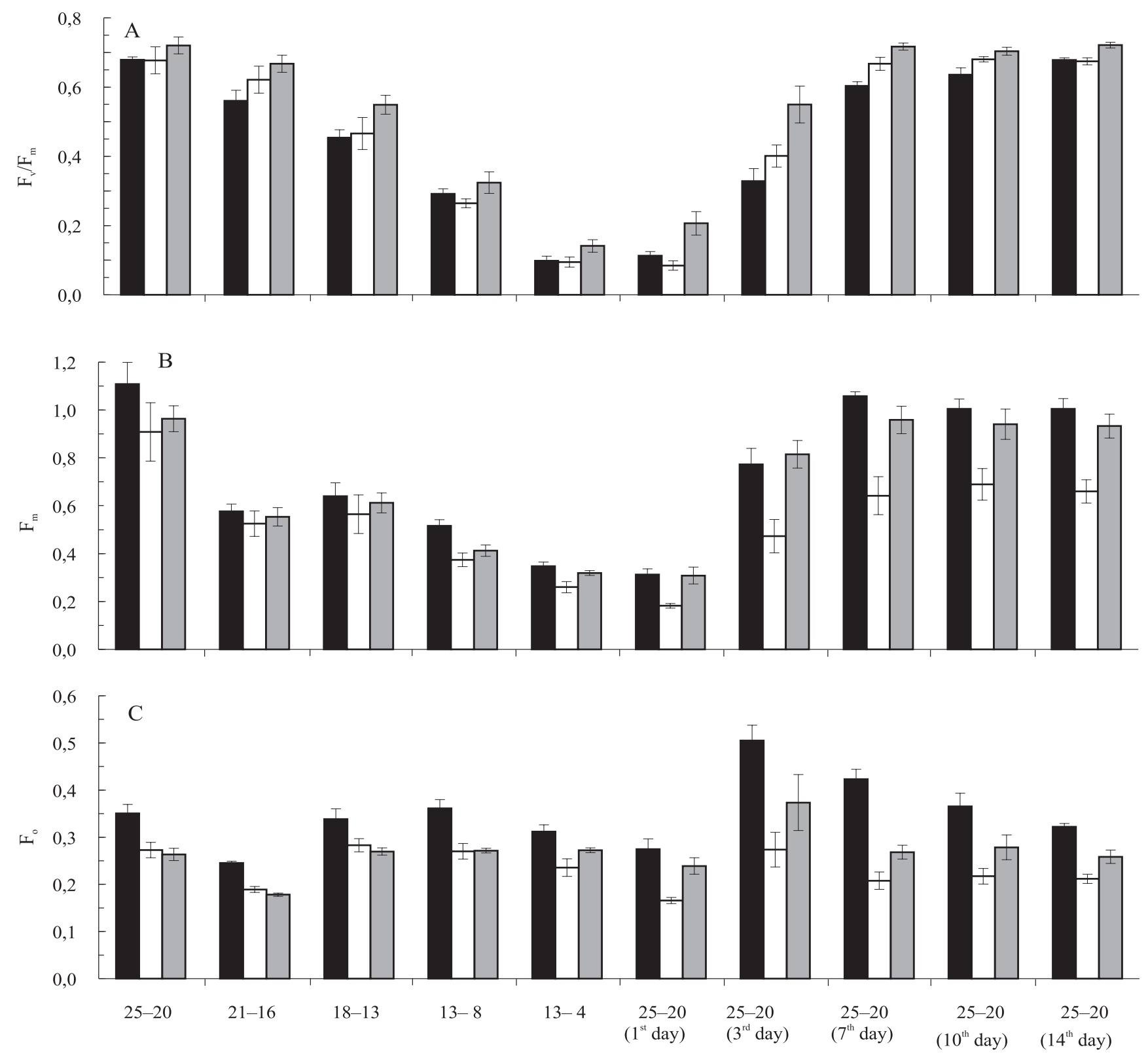

Diurnal-nocturnal temperature $\left({ }^{\circ} \mathrm{C}\right)$

Catucaí IPR $102 \square$ Conilon $02 \quad \square$ Conilon 153

Figure 3. Changes in: A, maximum quantum efficiency of PSII (Fv/Fm), LSD of 0.083 and 0.113 for genotypes and periods, respectively, and $\mathrm{CV}$ of $11.60 \%$; $\mathrm{B}$, maximum $\left(\mathrm{F}_{\mathrm{m}}\right)$, LSD of 0.185 and 0.251 for genotypes and periods, respectively, and CV of 19.03\%; and C, minimum ( $\left.\mathrm{F}_{\mathrm{o}}\right)$ fluorescence, LSD of 0.071 and 0.096 for genotypes and periods, respectively, and CV of 16.63\%. Results from Coffea sp. Catucaí IPR 102, Conilon 02 and Conilon 153 genotypes submitted to: a gradual decrease of temperature $\left(25-20^{\circ} \mathrm{C}\right.$ to $\left.13-8^{\circ} \mathrm{C}\right)$ for 24 days; three days at $13-4^{\circ} \mathrm{C}$; and a recovery period of 14 days at $25-20^{\circ} \mathrm{C}$. Bars represent standard error $(n=5)$. LSD, least significant difference; $C V$, coefficient of variation. 

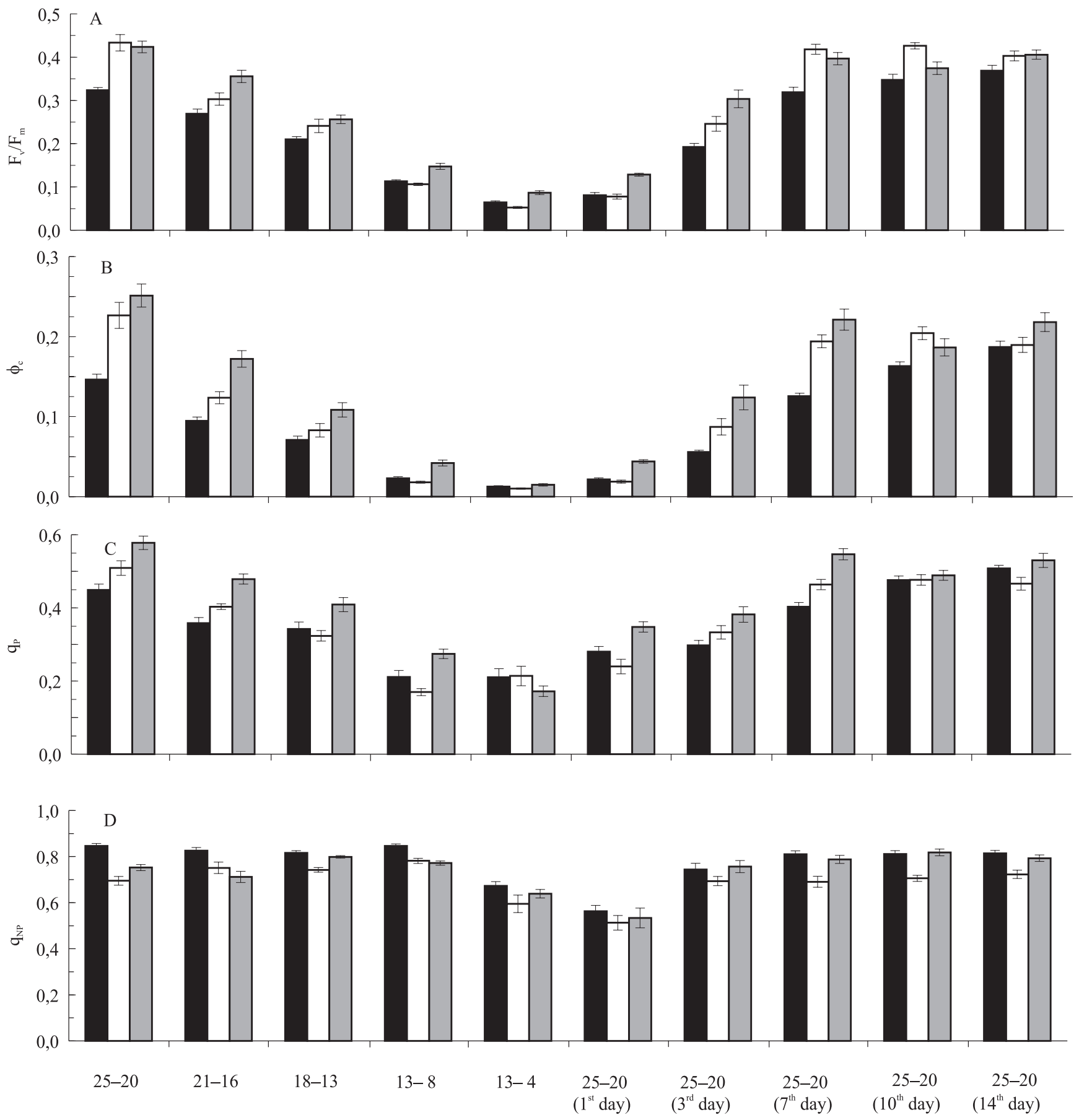

Diurnal-nocturnal temperature $\left({ }^{\circ} \mathrm{C}\right)$

Catucaí IPR $102 \square$ Conilon $02 \quad \square$ Conilon 153

Figure 4. Changes in: A, photochemical efficiency of PSII ( $\left.\mathrm{Fv}^{\prime} / \mathrm{Fm}^{\prime}\right)$, LSD of 0.037 and 0.050 for genotypes and periods, respectively, and $\mathrm{CV}$ of $21.27 \%$; B, estimate of quantum efficiency of linear electron transport $\left(\phi_{\mathrm{e}}\right)$, LSD of 0.027 and 0.036 for genotypes and periods, respectively, and CV of 35.64\%; C, photochemical ( $\mathrm{q}_{\mathrm{P}}$ ), LSD of 0.054 and 0.073 for genotypes and periods, respectively, and CV of 21.67\%; and D, nonphotochemical $\left(\mathrm{q}_{\mathrm{NP}}\right)$ quenchings, LSD of 0.067 and 0.091 for genotypes and periods, respectively, and CV of 13.87\%. Results from Coffea sp. Catucaí IPR 102, Conilon 02 and Conilon 153 genotypes submitted to: a gradual decrease of temperature $\left(25-20^{\circ} \mathrm{C}\right.$ to $\left.13-8^{\circ} \mathrm{C}\right)$ for 24 days; three days at $13-4^{\circ} \mathrm{C}$; and a recovery period of 14 days at $25-20^{\circ} \mathrm{C}$. Bars represent standard error $(n=25)$. $\mathrm{LSD}$, least significant difference; $\mathrm{CV}$, coefficient of variation. 
Hence, the reduction of $F_{m}, F_{v} / F_{m}$ and $F_{v}, F_{m}$, would contribute to the increase in nonphotochemical dissipation due to night retention and diurnal buildup of zeaxanthin (Table 1) (Demmig-Adams \& Adams III, 1992; Ramalho et al., 2000, 2003). That decrease can also be linked to the presence of photochemical inactive reaction centers of the PSII that dissipate thermal energy. These defense mechanisms compete for energy with photochemical events, but reduce the photochemical efficiency of PSII (Krause, 1994). However, the maintenance of lower $F_{m}$ in Conilon 02 and $F_{v} / F_{m}$, in all genotypes until the seventh day of recovery (Figure $4 \mathrm{~A}$ ), when the zeaxanthin level was similar in Conilon clones or lower in Catucaí IPR 102 than in the controls (Table 1), suggests the presence of some not readily reversible deleterious effects despite the recovery of $\mathrm{F}_{\mathrm{v}} / \mathrm{F}_{\mathrm{m}}$.

In fact, Conilon 02 showed degradation of chlorophyll (Table 2) during the recovery period, leading to significantly lower chlorophyll contents in comparison with its own control and with the other genotypes, and agreeing with the lower $\mathrm{F}_{\mathrm{m}}$ value. Since

Table 1. Changes in leaf carotenoid contents ( $\mu \mathrm{g} \mathrm{g}^{-1}$ dry matter) after two hours of illumination and in the night period (only zeaxanthin and DEPS) in the coffee genotypes Catucaí IPR 102 (Cat.), Conilon 02 and Conilon 153 exposed to a gradual decrease of temperature $\left(25 / 20^{\circ} \mathrm{C}\right.$ to $\left.13 / 8^{\circ} \mathrm{C}\right)$ for 24 days, to three days at $13 / 4^{\circ} \mathrm{C}$ and to a recovery period of 14 days at $25 / 20^{\circ} \mathrm{C}^{(1)}$.

\begin{tabular}{|c|c|c|c|c|c|c|}
\hline Genotypes & $25 / 20^{\circ} \mathrm{C}$ & $18 / 13^{\circ} \mathrm{C}$ & $13 / 8^{\circ} \mathrm{C}$ & $13 / 4^{\circ} \mathrm{C}$ & $25 / 20^{\circ} \mathrm{C}\left(7^{\text {th }}\right.$ day $)$ & $25 / 20^{\circ} \mathrm{C}\left(14^{\text {th }}\right.$ day $)$ \\
\hline & \multicolumn{6}{|c|}{ Alpha-carotene } \\
\hline Cat. IPR 102 & $59.6 \mathrm{Ba}$ & $34.2 \mathrm{Bb}$ & $13.5 \mathrm{Bc}$ & $8.2 \mathrm{Ac}$ & $11.6 \mathrm{Bc}$ & $26.8 \mathrm{Bb}$ \\
\hline Conilon 02 & $88.2 \mathrm{Aa}$ & $61.9 \mathrm{Ab}$ & $22.5 \mathrm{Ac}$ & $5.5 \mathrm{Ad}$ & $10.4 \mathrm{Bd}$ & $14.0 \mathrm{Ccd}$ \\
\hline Conilon 153 & $48.3 \mathrm{Ca}$ & $35.9 \mathrm{Bb}$ & $22.1 \mathrm{Ac}$ & $11.8 \mathrm{Ad}$ & $36.5 \mathrm{Ab}$ & $40.9 \mathrm{Aab}$ \\
\hline \multirow{2}{*}{$\mathrm{CV}$} & \multicolumn{6}{|c|}{$23.18 \%$} \\
\hline & \multicolumn{6}{|c|}{ Beta-carotene } \\
\hline Cat. IPR 102 & $157.0 \mathrm{Ba}$ & $110.4 \mathrm{Bb}$ & $73.9 \mathrm{Bb}$ & $68.4 \mathrm{Bd}$ & $86.4 \mathrm{Bcd}$ & $103.3 \mathrm{Bbc}$ \\
\hline Conilon 02 & $165.2 \mathrm{Ba}$ & $123.0 \mathrm{ABb}$ & $70.3 \mathrm{Bcd}$ & $65.6 \mathrm{Bd}$ & $78.2 \mathrm{Bcd}$ & $89.1 \mathrm{Bc}$ \\
\hline Conilon 153 & $201.4 \mathrm{Aa}$ & $138.4 \mathrm{Ab}$ & $134.2 \mathrm{Ab}$ & $100.9 \mathrm{Ac}$ & $141.5 \mathrm{Ab}$ & $133.6 \mathrm{Ab}$ \\
\hline \multirow[t]{2}{*}{$\mathrm{CV}$} & \multicolumn{6}{|c|}{$14.09 \%$} \\
\hline & \multicolumn{6}{|c|}{ Alpha/beta-carotene } \\
\hline Cat. IPR 102 & $0.38 \mathrm{Ba}$ & $0.31 \mathrm{Bab}$ & $0.18 \mathrm{Bcd}$ & $0.12 \mathrm{Ad}$ & $0.13 \mathrm{Bd}$ & $0.26 \mathrm{Abc}$ \\
\hline Conilon 02 & $0.54 \mathrm{Aa}$ & $0.53 \mathrm{Aa}$ & $0.32 \mathrm{Ab}$ & $0.08 \mathrm{Ac}$ & $0.13 \mathrm{Bc}$ & $0.16 \mathrm{Bc}$ \\
\hline Conilon 153 & $0.24 \mathrm{Aab}$ & $0.26 \mathrm{ba}$ & $0.16 \mathrm{Bbc}$ & $0.11 \mathrm{Ac}$ & $0.26 \mathrm{Aa}$ & $0.31 \mathrm{Aa}$ \\
\hline \multirow[t]{2}{*}{$\mathrm{CV}$} & \multicolumn{6}{|c|}{$22.51 \%$} \\
\hline & \multicolumn{6}{|c|}{ Lutein } \\
\hline Cat. IPR 102 & 718.4Aa & $558.1 \mathrm{Ab}$ & 444.5Acd & 486.6Abcd & $517.3 \mathrm{Abc}$ & 409.2Ad \\
\hline Conilon 02 & $473.8 \mathrm{Ba}$ & $447.0 \mathrm{Bab}$ & $358.2 \mathrm{Bbc}$ & $375.9 \mathrm{Bbc}$ & $294.7 \mathrm{Ccd}$ & $234.0 \mathrm{Bd}$ \\
\hline Conilon 153 & $516.1 \mathrm{Ba}$ & 421.7Bab & $509.9 \mathrm{Aa}$ & $413.8 \mathrm{ABb}$ & $398.5 \mathrm{Bb}$ & $339.5 \mathrm{Ab}$ \\
\hline \multirow[t]{2}{*}{$\mathrm{CV}$} & \multicolumn{6}{|c|}{$15.00 \%$} \\
\hline & \multicolumn{6}{|c|}{ Zeaxanthin (diurnal period) } \\
\hline Cat. IPR 102 & $235.5 \mathrm{Ab}$ & $268.6 \mathrm{Aab}$ & $238.3 \mathrm{Bb}$ & $284.5 \mathrm{Aa}$ & 109.3Ad & $163.0 \mathrm{Ac}$ \\
\hline Conilon 02 & $93.4 \mathrm{Cd}$ & $151.0 \mathrm{Cbc}$ & $189.9 \mathrm{Cb}$ & $236.9 \mathrm{Ba}$ & 80.2Ad & $117.2 \mathrm{Bcd}$ \\
\hline Conilon 153 & $180.3 \mathrm{Bc}$ & $223.3 \mathrm{Bbc}$ & $301.3 \mathrm{Aa}$ & $255.9 \mathrm{ABb}$ & 111.0Ad & $183.5 \mathrm{Ac}$ \\
\hline \multirow[t]{2}{*}{$\mathrm{CV}$} & \multicolumn{6}{|c|}{$15.86 \%$} \\
\hline & \multicolumn{6}{|c|}{ DEPS (diurnal period) } \\
\hline Cat. IPR 102 & $0.71 \mathrm{Ab}$ & $0.85 \mathrm{Aa}$ & $0.90 \mathrm{Aa}$ & $0.91 \mathrm{Aa}$ & $0.56 \mathrm{Ac}$ & $0.73 \mathrm{Ab}$ \\
\hline Conilon 02 & $0.50 \mathrm{Bd}$ & $0.78 \mathrm{Bb}$ & $0.90 \mathrm{Aa}$ & $0.92 \mathrm{Aa}$ & $0.61 \mathrm{Ac}$ & $0.78 \mathrm{Ab}$ \\
\hline Conilon 153 & $0.69 \mathrm{Ac}$ & $0.88 \mathrm{Aa}$ & $0.92 \mathrm{Aa}$ & $0.93 \mathrm{Aa}$ & $0.60 \mathrm{Ad}$ & $0.77 \mathrm{Ab}$ \\
\hline \multirow[t]{2}{*}{$\mathrm{CV}$} & \multicolumn{6}{|c|}{$6.29 \%$} \\
\hline & \multicolumn{6}{|c|}{ Zeaxanthin (nocturnal period) } \\
\hline Cat. IPR 102 & $65.1 \mathrm{Bd}$ & $111.8 \mathrm{Ac}$ & $148.5 \mathrm{Ab}$ & 193.3Aa & $35.7 \mathrm{Ae}$ & $37.1 \mathrm{ABe}$ \\
\hline Conilon 02 & $46.8 \mathrm{Cd}$ & $81.9 \mathrm{Bc}$ & $137.8 \mathrm{Ab}$ & 177.1Ba & $38.8 \mathrm{Ad}$ & $28.2 \mathrm{Bd}$ \\
\hline Conilon 153 & $89.8 \mathrm{Ac}$ & $116.2 \mathrm{Ab}$ & $105.9 \mathrm{Bbc}$ & $170.8 \mathrm{Ba}$ & 32.9Ad & 45.4Ad \\
\hline \multirow[t]{2}{*}{$\mathrm{CV}$} & \multicolumn{6}{|c|}{$14.84 \%$} \\
\hline & \multicolumn{6}{|c|}{ DEPS (nocturnal period) } \\
\hline Cat. IPR 102 & $0.44 \mathrm{Bd}$ & $0.62 \mathrm{Bc}$ & $0.74 \mathrm{ABb}$ & $0.80 \mathrm{Ba}$ & $0.33 \mathrm{Be}$ & $0.32 \mathrm{Be}$ \\
\hline Conilon 02 & $0.44 \mathrm{Bd}$ & $0.62 \mathrm{Bc}$ & $0.76 \mathrm{Ab}$ & $0.85 \mathrm{Aa}$ & $0.45 \mathrm{Ad}$ & $0.40 \mathrm{Ad}$ \\
\hline Conilon 153 & $0.49 \mathrm{Ac}$ & $0.67 \mathrm{Ab}$ & $0.70 \mathrm{Bb}$ & $0.87 \mathrm{Aa}$ & $0.31 \mathrm{Be}$ & $0.40 \mathrm{Ad}$ \\
\hline $\mathrm{CV}$ & \multicolumn{6}{|c|}{$7.21 \%$} \\
\hline
\end{tabular}


$F_{v} / F_{m}$ values were close to those of the control on the seventh day after chilling exposure and onwards, it can be assumed that the existing reaction centers are functional, but presumably in lower quantities. On the other hand, at the beginning of the recovery period (third day), $\mathrm{F}_{\mathrm{o}}$ increased in all genotypes, especially Catucaí IPR 102 and Conilon 153 (Figure 3 C). As referred by Ramalho et al. (2002), such rise in $F_{o}$ might be related to problems in light capture by the antenna pigments and to the transfer of excitation energy to the reaction center, that could be linked to inhibition of electron transfer between quinones $Q_{A}$ and $\mathrm{Q}_{\mathrm{B}}$, suggesting damage of the $\mathrm{D} 1$ protein (Dias \& Marenco, 2006). The observed recovery of this photoinactivation state is coherent with the gradual return of $F_{0}$ to the control values in Catucaí IPR 102 and Conilon 153 after the third day of recovery (Figure $3 \mathrm{C}$ ), which is concomitant with the recovery of the A rate (Figure $1 \mathrm{~A}$ ).

At $21 / 16^{\circ} \mathrm{C}, \phi_{\mathrm{e}}$ was strongly affected in the three genotypes, and showed minimal values (around 4-6\% of the control) after chilling exposure (Figure $4 \mathrm{~B}$ ), suggesting severe impact on electron transport, as reported in droughted coffee plants (DaMatta et al., 1997). Suzuki et al. (2008) maintained that this lower quantum-yield efficiency of linear electron transport, together with reduced activity in PSII (given by $\mathrm{F}_{\mathrm{v}}, /$ $\mathrm{F}_{\mathrm{m}}$ ), associated with the reduction in temperature, affected the decrease in the redox capability of quinones. Very low $\phi_{\mathrm{e}}$ values were still observed on the first day of recovery, justifying the negative values of A observed at this temperature, but complete recovery was observed on the seventh day.

The $\mathrm{q}_{\mathrm{P}}$ (Figure $4 \mathrm{C}$ ) reflects the reduced state of the first stable electron acceptor in PSII, with $\mathrm{Q}_{\mathrm{A}}$ providing an estimate of light energy driven to reduce $\mathrm{NADP}^{+}$. With the temperature drop, $\mathrm{q}_{\mathrm{P}}$ was strongly reduced, with maximal impacts of 55\% (Catucaí IPR 102), 60\% (Conilon 02) and 70\% (Conilon 153) after chilling exposure. However, some recovery had already occurred one day after the stress period ended, reaching values similar to those of the controls by the seventh day. The impact on $\mathrm{q}_{\mathrm{P}}$ was less severe than on $\mathrm{A}$ and $\phi_{e}$, which also shows faster recovery, suggesting the presence of alternative electron drains, cyclic electron

Table 2. Changes in chlorophyll leaf content and total carotenoids ( $\mathrm{mg} \mathrm{g}^{-1}$ dry matter), as well as in their ratios, after two hours of illumination, in three genotypes of Coffea sp., Catucaí IPR 102 (Cat.), Conilon 02 and Conilon 153, exposed to a gradual decrease of temperature $\left(25 / 20^{\circ} \mathrm{C}\right.$ to $\left.13 / 8^{\circ} \mathrm{C}\right)$ during 24 days, three days at $13 / 4^{\circ} \mathrm{C}$ and during the recovery period of 14 days at $25 / 20^{\circ} \mathrm{C}^{(1)}$.

\begin{tabular}{|c|c|c|c|c|c|c|}
\hline Genotype & $25 / 20^{\circ} \mathrm{C}$ & $18 / 13^{\circ} \mathrm{C}$ & $13 / 8^{\circ} \mathrm{C}$ & $13 / 4^{\circ} \mathrm{C}$ & $25 / 20^{\circ} \mathrm{C}\left(7^{\text {th }}\right.$ day $)$ & $25 / 20^{\circ} \mathrm{C}\left(14^{\text {th }}\right.$ day $)$ \\
\hline & \multicolumn{6}{|c|}{ Chlorophyll $a$} \\
\hline Cat. IPR 102 & $3.40 \mathrm{Ba}$ & $3.33 \mathrm{Aa}$ & $2.40 \mathrm{Bb}$ & $2.38 \mathrm{Ab}$ & $2.31 \mathrm{Bb}$ & $2.53 \mathrm{Ab}$ \\
\hline Conilon 02 & $3.70 \mathrm{Ba}$ & 3.39Aa & $2.37 \mathrm{Bb}$ & $2.02 \mathrm{Abc}$ & $1.47 \mathrm{Cc}$ & $1.49 \mathrm{Bc}$ \\
\hline Conilon 153 & $4.45 \mathrm{Aa}$ & $3.36 \mathrm{Ab}$ & $3.37 \mathrm{Ab}$ & $2.40 \mathrm{Ac}$ & $2.96 \mathrm{Abc}$ & $2.81 \mathrm{Abc}$ \\
\hline \multirow[t]{2}{*}{$\mathrm{CV}$} & \multicolumn{6}{|c|}{$17.85 \%$} \\
\hline & \multicolumn{6}{|c|}{ Chlorophyll $b$} \\
\hline Cat. IPR 102 & $1.34 \mathrm{ABa}$ & $1.37 \mathrm{Aa}$ & $0.96 \mathrm{ABb}$ & $0.98 \mathrm{Ab}$ & $0.91 \mathrm{Ab}$ & $0.90 \mathrm{Ab}$ \\
\hline Conilon 02 & $1.21 \mathrm{Ba}$ & $1.16 \mathrm{Aa}$ & $0.84 \mathrm{Bb}$ & $0.73 \mathrm{Bb}$ & $0.44 \mathrm{Bc}$ & $0.39 \mathrm{Bc}$ \\
\hline Conilon 153 & $1.49 \mathrm{Aa}$ & $1.14 \mathrm{Ab}$ & $1.16 \mathrm{Ab}$ & $0.88 \mathrm{ABb}$ & $0.97 \mathrm{Ab}$ & $0.96 \mathrm{Ab}$ \\
\hline \multirow[t]{2}{*}{$\mathrm{CV}$} & \multicolumn{6}{|c|}{$19.86 \%$} \\
\hline & \multicolumn{6}{|c|}{ Chlorophyll $a+b$} \\
\hline Cat. IPR 102 & $4.74 \mathrm{Ba}$ & 4.70Aa & $3.37 \mathrm{Bb}$ & $3.36 \mathrm{Ab}$ & $3.22 \mathrm{Ab}$ & $3.43 \mathrm{Ab}$ \\
\hline Conilon 02 & $4.91 \mathrm{Ba}$ & $4.55 \mathrm{Aa}$ & $3.21 \mathrm{Bb}$ & $2.75 \mathrm{Abc}$ & $1.91 \mathrm{Bc}$ & $1.88 \mathrm{Bc}$ \\
\hline Conilon 153 & $5.94 \mathrm{Aa}$ & $4.50 \mathrm{Ab}$ & $4.53 \mathrm{Ab}$ & $3.27 \mathrm{Ac}$ & $3.93 \mathrm{Abc}$ & $3.77 \mathrm{Abc}$ \\
\hline \multirow[t]{2}{*}{$\mathrm{CV}$} & \multicolumn{6}{|c|}{$18.18 \%$} \\
\hline & \multicolumn{6}{|c|}{ Total carotenoids } \\
\hline Cat. IPR 102 & 1.42ABab & $1.44 \mathrm{Aa}$ & $1.14 \mathrm{Bc}$ & $1.28 \mathrm{Aabc}$ & $1.19 \mathrm{Abc}$ & $1.18 \mathrm{Abc}$ \\
\hline Conilon 02 & $1.29 \mathrm{Ba}$ & $1.24 \mathrm{Aa}$ & $1.12 \mathrm{Ba}$ & 1.19Aa & $0.81 \mathrm{Bb}$ & $0.77 \mathrm{Bb}$ \\
\hline Conilon 153 & $1.55 \mathrm{Aa}$ & $1.24 \mathrm{Abc}$ & $1.37 \mathrm{Aab}$ & $1.14 \mathrm{Abc}$ & $1.09 \mathrm{Ac}$ & $1.02 \mathrm{Ac}$ \\
\hline \multirow[t]{2}{*}{$\mathrm{CV}$} & \multicolumn{6}{|c|}{$14.28 \%$} \\
\hline & \multicolumn{6}{|c|}{ Chlorophyll $(a+b) /$ Total carotenoids } \\
\hline Cat. IPR 102 & $3.35 \mathrm{Ba}$ & $3.26 \mathrm{Bab}$ & $2.94 \mathrm{Bbc}$ & $2.61 \mathrm{Ac}$ & $2.68 \mathrm{Bc}$ & $2.90 \mathrm{Bbc}$ \\
\hline Conilon 02 & $3.79 \mathrm{Aa}$ & $3.63 \mathrm{Aa}$ & $2.87 \mathrm{Bb}$ & $2.27 \mathrm{Bc}$ & $2.35 \mathrm{Cc}$ & $2.43 \mathrm{Cc}$ \\
\hline Conilon 153 & $3.84 \mathrm{Aa}$ & $3.62 \mathrm{Aab}$ & $3.32 \mathrm{Ab}$ & $2.83 \mathrm{Ac}$ & $3.58 \mathrm{Aab}$ & 3.68Aab \\
\hline
\end{tabular}
coefficient of variation. 
transport around PSI, and photorespiration (Ribeiro et al., 2004).

The $\mathrm{q}_{\mathrm{NP}}$ (Figure 4 D) reflects heat dissipation processes, namely those related to the increase of trans-thylakoid proton electrochemical potential difference $(\Delta \mathrm{pH})$ (Maxwell \& Johnson, 2000). This parameter maintained high values during most of the experiment, denoting high nonphotochemical energy dissipation related to the $P s b S$ protein, which is closely associated with the PSII reaction center. After protonation, $P s b S$ triggers conformational changes in the thylakoid membrane which are necessary for $\mathrm{q}_{\mathrm{E}}$ (the main component of $\mathrm{q}_{\mathrm{NP}}$, known as "high-energy quenching"), promoting a direct interaction between chlorophyll and zeaxanthin (Müller et al., 2001; Ma et al., 2003). However, $\mathrm{q}_{\mathrm{NP}}$ decreased after chilling exposure and in the first day of recovery, when $\phi_{\mathrm{e}}$ was strongly suppressed, which might have prevented $\Delta \mathrm{pH}$ buildup and decreased effectiveness of this mechanism. Nevertheless, it must be taken into account that $\mathrm{q}_{\mathrm{NP}}$ compares changes between light and dark-adapted status. Since $F_{m}$ values probably decreased due to night retention of zeaxanthin (Table 1), $\mathrm{q}_{\mathrm{NP}}$ values will only quantify further increases in thermal dissipation ability in light conditions, but not in the total sustained thermal dissipation (Maxwell \& Johnson, 2000; Ramalho et al., 2003), which leads to an "erroneously" lower $\mathrm{q}_{\mathrm{NP}}$ value.

The analysis of the photosynthetic pigments will give insights on the impact of stress on the photosynthetic apparatus. Amongst them, carotenoids are especially important, since they contribute to the stability of light-harvesting antenna complexes, the dissipation of excess excitation energy and the reactive oxygen species scavenging (Demmig-Adams et al., 1995). With low-temperature exposure, chlorophylls $a$ and $b$ were severely reduced in all genotypes (Table 2). This loss was further increased in Conilon 02 during recovery, when the chlorophyll $(a+b)$ rate dropped to $38 \%$ of the control. The strongest impact was on chlorophyll $a$.

Total carotenoids also diminuished, with Conilon 02 showing the strongest reduction, particularly during the recovery period (Table 2). Nevertheless, carotenoids were less affected than chlorophylls, leading to a decrease in ratio (total chlorophyll/total carotenoids) in all genotypes, as observed in maize (Holá et al., 2007). This ratio decrease resulting from a stronger reduction of energy-capture pigments could be considered a response to low capture of excessive light energy under stress conditions. However, by the end of the experiment, despite the clear decrease in this ratio (to $60 \%$ of initial value) in Conilon 02 , the massive pigment loss $(38 \%$ of total chlorophylls and $60 \%$ of total carotenoids, reflected in a yellowish-green color of the leaves), suggests failures of photosynthetic mechanisms rather than a positive response to cold exposure. This could be linked to photobleaching phenomena, thus contributing to the poorest $A$ recovery fourteen days after chilling exposure.

Values of zeaxanthin and the de-epoxidation status (DEPS) involving the zeaxanthin cycle components increased in all genotypes with the exposure to low temperatures during the day (Table 1), in agreement with results reported for other coffee genotypes (Ramalho et al., 2003). DEPS and zeaxanthin values were significantly higher in Catucaí IPR 102 and in Conilon 153 in comparison to Conilon 02 to $18 / 13^{\circ} \mathrm{C}$ and $13 / 8^{\circ} \mathrm{C}$ respectively (Table 1 ). This shows a higher thermal dissipation capability in those genotypes that could prevent the production of highly reactive molecules $\left({ }^{3} \mathrm{Chl},{ }^{1} \mathrm{Chl},{ }^{1} \mathrm{O}_{2}, \mathrm{H}_{2} \mathrm{O}_{2}\right)$. Photoprotective pigments also avoid the over-reduction of the thylakoid electron transport chain and the over-acidification of the thylakoid lumen, which are known to trigger photoinduced PSII damages (Müller et al., 2001). Furthermore, zeaxanthin (together with lutein and beta-carotene) may also scavenge some of those highly reactive molecules, which are usually overproduced under stress conditions (Niyogi, 1999). After chilling, Catucaí IPR 102 still showed higher zeaxanthin content than Conilon 02 , but upon recovery at $25 / 20^{\circ} \mathrm{C}$ zeaxanthin levels tended towards the control values in Conilon clones, or to lower values in Catucaí IPR 102. Those findings confirm the role of the xanthophyll cycle as an important flexible mechanism that regulates PSII activity and avoids an energy overload in the photosynthetic apparatus in Coffea sp., as found with low temperature (Ramalho et al., 2003), water deficit (Cai et al., 2007) and high irradiance (Ramalho et al., 2000).

Concerning the xanthophyll cycle, what happens during the night is noteworthy. In the controls, zeaxanthin and DEPS of dark collected samples showed values clearly below those obtained under light (Table 1). Those values gradually increased with cold 
exposure, showing maximum values after chilling, but still below the diurnal ones. As stated above, such retention will decrease the photochemical efficiency of PSII $\left(\mathrm{F}_{\mathrm{v}} / \mathrm{F}_{\mathrm{m}}\right)$, and was suggested as coming from the sensitivity of zeaxanthin epoxidase to cold and from the partial maintenance of the $\Delta \mathrm{pH}$ during the night, since ATPase does not perform $\mathrm{H}^{+}$transport across the thylakoid membrane under cold exposure (Gilmore, 1997).

Lutein also has an important photoprotective role in the photosystems and in the stability of the energy-capturing complexes (Pogson et al., 1998; Niyogi, 1999). Xanthophyll strongly decreased in all genotypes afterchilling, with Conilon 153 being affected later than the other two genotypes. Nevertheless, values were consistently higher in Catucaí IPR 102 throughout the entire experiment when compared to Conilon 02, and Conilon 153 usually assumed intermediate values (Table 1), which confirms earlier results comparing C. arabica cv. Icatu with C. canephora cv. Apoatã (Ramalho et al., 2003).

Alpha and beta-carotene values significantly decreased with low temperatures $\left(13 / 4^{\circ} \mathrm{C}\right)$ (Table 1$)$, reaching 86 and 56\% in Catucaí IPR 102, 76 and $50 \%$ in Conilon 153 and 94 and 60\% in Conilon 02 respectively. This could lead to impairments at the PS level, since beta-carotene is essential for its aggregation and photoprotection (Pogson et al., 1998) through ${ }^{3} \mathrm{Chl}$ and ${ }^{1} \mathrm{O}_{2}$ inactivation, releasing energy as heat (Niyogi, 1999). The (alpha/beta) carotene ratio also decreased with low temperatures, but tended to rise to the initial values in Conilon 153 upon recovery (Table 1). This reduction, interpreted as a leaf response to cold, was reported from coffee plants exposed to cold (Ramalho et al., 2003) and high irradiation (Ramalho et al., 2000). However, these reports assumed that the reduction results from a beta-carotene rise that increases photoprotection, as in C. arabica cv. Icatu (Ramalho et al., 2003), differently from what was observed in this work, which showed beta-carotene decreases of $50 \%$ or higher at $13 / 4^{\circ} \mathrm{C}$ and a partial recovery thereafter.

\section{Conclusions}

1. All coffee genotypes show sensitivity to low temperature at the stomatal, biochemical and biophysical levels.
2. When photosynthetic parameters are considered (gas exchange and fluorescence), Catucaí IPR 102 presents the best performance after exposure to chill.

3. No significant differences were observed with the enzymes involved in the photosynthetic pathway (Rubisco and Ru5PK), among genotypes exposed to chill, although all genotypes show consistent decline in enzyme activity.

4. Catucaí IPR 102 shows higher contents of the zeaxanthin and lutein pigments than clone 02, and frequently higher than clone 153 as well.

5. Catucaí IPR 102 presents improved recoverying ability than the Conilon clones.

\section{Acknowledgements}

To Dr. Tumoru Sera and to Gabriel Burgarelli, for the Catucaí IPR 102 and Conilon plant materials; to Coordenação de Aperfeiçoamento de Pessoal de Nível Superior, for a scholarship; to Fundação para a Ciência e Tecnologia and to the European Fund FEDER, for partial support of this work.

\section{References}

CAI, C.-T.; CAI, Z.-Q.; YAO, T.-Q.; QI, X. Vegetative growth and photosynthesis in coffee plants under different watering and fertilization managements in Yunnan, SW China. Photosynthetica, v.45, p.455-461, 2007.

CAMPOS, P.S.; QUARTIN, V.; RAMALHO, J.C.; NUNES, M.A. Electrolyte leakage and lipid degradation account for cold sensitivity in leaves of Coffea sp. plants. Journal of Plant Physiology, v.160, p.283-292, 2003.

DAMATTA, F.M.; MAESTRI, M.; MOSQUIM, P.R.; BARROS, R.S. Photosynthesis in coffee (Coffea arabica and C. canephora) as affected by winter and summer conditions. Plant Science, v.128, p.43-50, 1997.

DAVIS, A.P.; GOVAERTS, R.; BRIDSON, D.M.; STOFFELEN, P. An annotated taxonomic conspectus of the genus Coffea (Rubiaceae). Botanical Journal of the Linnean Society, v.152, p.465-512, 2006.

DEMMIG-ADAMS, B.; ADAMS III, W.W. Photoprotection and other responses of plants to high light stress. Annual Review of Plant Physiology and Plant Molecular Biology, v.43, p.599-626, 1992.

DEMMIG-ADAMS, B.; ADAMS III, W.W.; LOGAN, B.A.; VERHOEVEN, A.S. Xanthophyll cycle-dependent energy dissipation and flexible photosystem II efficiency in plants acclimated to light stress. Australian Journal of Plant Physiology, v.22, p.249-260, 1995. 
DIAS, D.P.; MARENCO, R.A. Photoinhibition of photosynthesis in Minquartia guianensis and Swietenia macrophylla inferred by monitoring the initial fluorescence. Photosynthetica, v.44, p.235-240, 2006.

FREDEEN, A.L.; RAAB, T.K.; RAO, I.M.; NORMAN, N. Effects of phosphorus nutrition on photosynthesis in Glycine max (L.) Merr. Planta, v.181, p.399-405, 1990.

GENTY, B.; BRIANTAIS, J.-M.; BAKER, N.R. The relationship between the quantum yield of photosynthetic electron transport and quenching of chlorophyll fluorescence. Biochimica et Biophysica Acta, v.990, p.87-92, 1989.

GILMORE, A.M. Mechanistic aspects of xanthophyll cycle-dependent photoprotection in higher plant chloroplasts and leaves. Physiologia Plantarum, v.99, p.197-209, 1997.

HOLÁ, D.; KOČOVÁ, M.; ROTHOVÁ, O.; WILHELMOVÁ, N.; BENEŠOVÁ, M. Recovery of maize (Zea mays L.) inbreds and hybrids from chilling stress of various duration: photosynthesis and antioxidant enzymes. Journal of Plant Physiology, v.164, p.868-877, 2007.

KOOTEN, O. van; SNELL, J.F.H. The use of chlorophyll fluorescence nomenclature in plant stress physiology. Photosynthesis Research, v.25, p.147-150, 1990.

KRAUSE, G.H. Photoinhibition induced by low temperature. In: BAKER, N.R.; BOWYER, J.R. (Ed.). Photoinhibition of photosynthesis: from molecular mechanisms to the field. Oxford: Bios Scientific Publishers, 1994. p.331-348. (Environmental Plant Biology Series).

KRÜPA, Z.; ÖQUIST, G.; HUNER, N.P. The effects of cadmium on photosynthesis of Phaseolus vulgaris: a fluorescence analysis. Physiologia Plantarum, v.88, p.626-630, 1993.

LICHTENTHALER, H.K. Chlorophylls and carotenoids: pigments of photosynthetic biomembranes. Methods in Enzimology, v.148, p.350-382, 1987.

MA, Y.-Z.; HOLT, N.F.; LI, X.-P.; NIYOGI, K.K.; FLEMING, G.R. Evidence for direct carotenoid involvement in the regulation of photosynthetic light harvesting. Proceedings of the National Academy of Sciences of the United States of America, v.100, p.4377-4382, 2003.

MAROCO, J.P.; EDWARDS, G.E.; KU, M.S.B. Photosynthetic acclimation of maize to growth under elevated levels of carbon dioxide. Planta, v.210, p.115-125, 1999.

MAXWELL, K.; JOHNSON, G.N. Chlorophyll fluorescence - a practical guide. Journal of Experimental Botany, v.51, p.659-668, 2000 .

MÜLLER, P.; LI, X-P.; NIYOGI, K.K. Non-photochemical quenching. A response to excess light energy. Plant Physiology, v.125, p.1558-1566, 2001.
NIYOGI, K.K. Photoprotection revisited: genetic and molecular approaches. Annual Review of Plant Physiology and Plant Molecular Biology, v.50, p.333-359, 1999.

POGSON, B.J.; NIYOGI, K.K.; BJÖRKMAN, O.; DELLAPENNA, D. Altered xanthophyll compositions adversely affected chlorophyll accumulation and nonphotochemical quenching in Arabidopsis mutants. Proceedings of the National Academy of Sciences of the United States of America, v.95, p.13324-13329, 1998.

RAMALHO, J.C.; MARQUES, N.C.; SEMEDO, J.N.; MATOS, M.C.; QUARTIN, V.L. Photosynthetic performance and pigment composition of leaves from two tropical species is determined by light quality. Plant Biology, v.4, p.112-120, 2002.

RAMALHO, J.C.; PONS, T.L.; GROENEVELD, H.W.; AZINHEIRA, H.G.; NUNES, M.A. Photosynthetic acclimation to high light conditions in mature leaves of Coffea arabica L.: role of xanthophylls, quenching mechanisms and nitrogen nutrition. Australian Journal of Plant Physiology, v.27, p.43-51, 2000.

RAMALHO, J.C.; PONS, T.L.; GROENEVELD, H.W.; NUNES, M.A. Photosynthetic responses of Coffea arabica leaves to a short-term high light exposure in relation to $\mathrm{N}$ availability. Physiologia Plantarum, v.101, p.229-239, 1997.

RAMALHO, J.C.; QUARTIN, V.L.; LEITÃO, E.; CAMPOS, P.S.; CARELLI, M.L.C.; FAHL, J.I.; NUNES, M.A. Cold acclimation ability and photosynthesis among species of the tropical Coffea genus. Plant Biology, v.5, p.631-641, 2003.

RIBAS-CARBO, M.; AROCA, R.; GONZÀLEZ-MELER, M.A.; IRIGOYEN, J.J.; SÁNCHEZ-DÍAZ, M. The electron partitioning between the cytochrome and alternative respiratory pathways during chilling recovery in two cultivars of maize differing in chilling sensitivity. Plant Physiology, v.122, p.199-204, 2000.

RIBEIRO, R.V.; MACHADO, E.C.; OLIVEIRA, R.F. Growth and leaf temperature effects on photosynthesis of sweet orange plants infected with Xylella fastidiosa. Plant Pathology, v.53, p.334-340, 2004.

SCHINDLER, C.; REITH, P.; LICHTENTHALER, H.K. Differential levels of carotenoids and decrease of zeaxanthin cycle performance during leaf development in a green and an aurea variety of tobacco. Journal of Plant Physiology, v.143, p.500-507, 1994.

SILVA, E.A.; DAMATTA, F.M.; DUCATTI, C.; REGAZZI, A.J.; BARROS, R.S. Seasonal changes in vegetative growth and photosynthesis of Arabica coffee trees. Field Crops Research, v.89, p.349-357, 2004.

SUZUKI, K.; NAGASUGA, K.; OKADA, M. The chilling injury induced by high root temperature in the leaves of rice seedlings. Plant and Cell Physiology, v.49, p.433-442, 2008.

Recebido em 11 de maio de 2009 e aprovado em 29 de outubro de 2009 